\begin{tabular}{|l|l|l||}
\hline \multicolumn{2}{|c|}{ PublisherInfo } \\
\hline \hline PublisherName & $:$ & BioMed Central \\
\hline \hline PublisherLocation & $:$ & London \\
\hline \hline PublisherImprintName & $:$ & BioMed Central \\
\hline \hline
\end{tabular}

\title{
Generation of human tumors in vitro
}

\begin{tabular}{||l|l|l||}
\hline \multicolumn{2}{|c||}{ ArticleInfo } \\
\hline \hline ArticleID & $:$ & 3622 \\
\hline \hline ArticleDOI & $:$ & $10.1186 /$ bcr-1999-66600 \\
\hline \hline ArticleCitationID & $:$ & 66600 \\
\hline \hline ArticleSequenceNumber & $:$ & 42 \\
\hline \hline ArticleCategory & $:$ & Paper Report \\
\hline \hline ArticleFirstPage & $:$ & 1 \\
\hline \hline ArticleLastPage & $:$ & 3 \\
\hline \hline & & RegistrationDate : 1999-8-3 \\
ArticleHistory & $:$ & OnlineDate $\quad$ 1999-8-3 \\
\hline \hline ArticleCopyright & $:$ & Current Science Ltd1999 \\
\hline \hline ArticleGrants & $:$ & \\
\hline \hline ArticleContext & $:$ & 1305811 \\
\hline \hline
\end{tabular}




\section{Keywords}

mutation, oncogenes, telomerase, transformation

\section{Introduction}

Tumorigenesis is a multistep process involving the acquisition of genetic mutations which override events controlling normal proliferation. The cumulative effects eventually lead to anchorageindependent growth and survival in the absence of growth factors. Although normal rodent cells can be made tumorigenic in vitro, attempts to achieve the same with human cells have been unsuccessful.

\section{Aims}

This paper set out to determine the minimum number of defined genetic events necessary to achieve the formation of human tumor cells in vitro.

\section{Comments}

This is a landmark paper which demonstrates that co-operation of genes is required for cellular transformation. Disruption of the intracellular pathways controlled by these genes, in particular the order in which these events occur, may be of fundamental importance in tumorigenesis.

\section{Methods}

To ensure any observations were not confined to a particular cell type, both normal human epithelial and fibroblast cells were used. Combinations of genes encoding hTERT (the catalytic subunit of telomerase, which maintains telomere length), oncogenic ras (H-rasV12, which induces transformation and cell growth in the absence of growth factors) and SV40 large-T oncoprotein (which inactivates the p53 and pRb pathways) were serially introduced using amphotrophic retroviruses into each cell type. 
Effects on cell growth and the ability of these cells to form colonies in soft agar and to form tumors in nude mice was determined.

\section{Results}

Introduction of ras or hTERT genes alone or both genes induced senescence. However, cells expressing large-T and hTERT became immortalised; when combined with Ras expression, morphological transformation was evident with a slight increase in cell growth. Cells expressing combinations of large-T, Ras and hTERT formed colonies in soft agar and were tumorigenic when introduced into nude mice, forming rapidly growing tumors with histological features akin to those of malignant tumors. These results were consistent in both fibroblasts and epithelial cells.

\section{Discussion}

These results have illustrated that co-expression of three genes (the large-T, ras and hTERT genes) is sufficient to cause tumor growth. At least four distinct intracellular signalling pathways are likely to be involved, one more than is required for the transformation of rodent cells. As well as alterations in telomere maintenance controlled by hTERT and growth promoting pathways governed by Ras, large-T can bind to and inactivate the p53 and pRb pathways. Large-T can also affect other signalling pathways; therefore it remains to be determined whether or not disruption of these pathways may also be necessary for tumorigenesis.

\section{References}

1. Hahn WC, Counter CM, Lundberg AS, Beijersbergen RL, Brooks MW, Weinberg RA: Creation of human tumor cells with defined genetic elements. Nature. 1999, 400: 464-468. 